\title{
Feminist Ecological Economics and Sustainability
}

\author{
PATRICIA E. PERKINS \\ Faculty of Environmental Studies, York University, Toronto, ON M3J 1P3, Canada \\ (esperk@yorku.ca)
}

\begin{abstract}
Synopsis: New developments in feminist ecological economics and ecofeminist economics are contributing to the search for theories and policy approaches to move economies toward sustainability. This paper summarizes work by ecofeminists and feminist ecological economists which is relevant to the sustainability challenge and its implications for the discipline of economics. Both democracy and lower material throughputs are generally seen as basic principles of economic sustainability. Feminist theorists and feminist ecological economists offer many important insights into the conundrum of how to make a democratic and equity-enhancing transition to an economy based on less material throughput. These flow from feminist research on unpaid work and caring labor, provisioning, development, valuation, social reproduction, non-monetized exchange relationships, local economies, redistribution, citizenship, equity-enhancing political institutions, and labor time, as well as creative modeling approaches and activism-based theorizing.
\end{abstract}

Key words: feminist economics, ecological economics, sustainable development, unpaid work, economic valuation, caring labor, material throughput, economic growth, gender, equity, social reproduction, local economies, social change, sustaining services, social sustainability, feminism, provisioning, sustainable livelihoods, service sector, quality of life, work time, multi-tasking, discourse-based valuation, community economies, social resilience

JEL classification: B54，D10，D13，D19，D46，D62，D63，D64，E26，F01，J16，Q56，Q57

\section{Introduction}

This paper provides a short overview of recent work in feminist economics, ecofeminism, and feminist ecological economics, that relates to the debate surrounding the transition to more sustainable, less resource-dependent economies and societies. It is important for ecological economists to be aware of - and to draw from -these feminist sources, since a gendered analysis identifies structural reasons for the systematic 'externalization' of both the natural environment and gendered, unpaid work in existing economic systems. ${ }^{1}$ Feminist scholars, in theorizing gender and economics, have many insights to offer ecological economists.

A sustainable socio-economy is one which, while democratically creating the possibility of meaningful, equitable, and pleasant lives for all people in the present, does not destroy either its ecological foundations or its capacity for social and physical reproduction into the future. Feminist documentation, commentary, theorizing, and activism on these issues provide crucial contributions to humanity's collective understanding of how to bring more sustainable socio-economies into 
being. Much of feminist economics, like much of ecological economics, critiques the growth-based capitalist economic paradigm and proposes various kinds of policies to modify market systems and reduce open access for capital on equity and sustainability grounds. A shared analysis, bringing together concerns for 'nature' and concerns for equity (including intraspecies, interspecies, and intergenerational balancing) is long overdue.

While explicit recognition of the links between feminist work and ecological economics is rare and the contributions are many, a number of ecological economists have been bringing ideas into their analysis which can be termed 'feminist' or which are related to key themes in the feminist economics or ecofeminist literatures. This paper points out some of these connections.

\section{Describing the democratic transition to lower material throughput}

Ecological economics has been very concerned with how to reduce the material throughput of economies without stalling the growth on which employment depends, or reducing people's standards of living. Since many of the earth's physical resources are finite, but human populations and the material-intensity of economies continue to increase, throughput reduction is often framed as a zero-sum game in which those material resources used by one person or group must become unavailable for use by others. This raises the spectre of inevitable conflict over resources, and places sustainable economies in a framework where it is hard to imagine people freely choosing them in a democratic context; instead, it is assumed in this framework that the transition to sustainability will be forced upon unwilling populations by rising prices and scarcity. Moreover, rectifying unjust distribution of economic assets and opportunities (e.g. on gender, class, or global lines) is seen as fraught with conflict; if the pie is not growing, how can some be given larger shares? ${ }^{2}$

Since democracy, equity, and lower use of material inputs - especially nonrenewable ones - are all important components of most visions of a sustainable socio-economy, this perceived tension between free choice, justice, and reduced throughput is highly problematic.

However, some ecological economists have indicated two potential ways around this conundrum. One is to conceptually de-link economic growth from resource throughput, so that growth is seen as stemming from human-produced value using fewer and fewer raw materials. In other words, growth can be defined as a gain in the amounts of economic and social value from the same quantum of physical inputs, which may in fact be recycled. Economic value can be created by human ingenuity and endeavour in ways which increase the efficiency of use of raw materials, defined in economic terms, so that the economy continues to grow with no, or very little, increased throughput. ${ }^{3}$ This does not violate the laws of thermodynamics since vast amounts of renewable and human energy, which are constrained 
on the earth only by the amount of incoming solar energy and efficiencies of conversion/use, may be transformed into economic value in this way.

Terming this process 'service-based growth', or more misleadingly 'dematerialization', does not fully capture its potential for transforming how people understand economic progress or development. On the contrary, what is required is a new way of thinking about the factors that mediate human embeddedness in the natural environment, and how people can affect this relationship. ${ }^{4}$ The ecological economics literature has taken up the question of the need to distinguish between throughput-derived economic growth and materially-independent growth as a basis for development. ${ }^{5}$ For example, the Wuppertal Institute's 'Material Intensity per Service Unit' indicator compares material inputs with total economic services provided; work by Faye Duchin, Manfred Max-Neef, Tim Jackson and others also addresses the social determinants of economic value, satisfaction, and quality of life in relation to material consumption (Martinez-Alier 1999, pp. 127-128).

The second approach which conceptually allows for reduced throughput along with economic growth and development is also, in a sense, about redefining terms. As previously-uncounted and unrecognized inputs to economic well-being (such as unpaid work and environmental services) begin to be counted and added into the reckoning, the notion of what is understood as the economy is enlarged, and 'growth' is produced which is not materially-derived. ${ }^{6}$ This approach acknowledges and counts things that were happening all along as 'growth'. Recognizing unpaid services as crucial to the economy tends to allow them to expand and flourish, if barriers to their expansion are subsequently removed. This in turn generates new growth and development that is not, or not mainly, derived from material throughput.

Not viewing the transition to sustainability as a zero-sum game (with inevitable conflict) is a key aspect of these two approaches. They allow the possibility of envisioning a democratic, creative, and diverse transition to sustainability, driven by human ingenuity with no limit to the value and well-being which may be produced within the framework of social justice, renewable energy and reused/recycled materials.

Both of these approaches are examples of a tactic or methodology which is often used in feminist analysis: the grounded and identity-conscious, relationship-based reframe. This kind of reframe allows us to see things which may have been 'hidden in plain sight' when economic actors were seen as individual utility-maximizers, and unmarketed goods and services were not seen at all.

In the words of Rosi Braidotti (1999, p. 86, 91, 95), conceptual creativity in transforming the 'social imaginary' and a 'new understanding of the (knowing) human subject as embedded,' within a specific material and grounded reality, are essential to the cultural changes which work 'in the direction of a sustainable subject.'

Feminist philosophers such as Val Plumwood, Lorraine Code, Teresa Brennan, Sandra Harding, Julia Kristeva, and Chris Cuomo have made crucial contributions 
to defining and problematizing the concepts of 'nature' and 'sustainability' from feminist perspectives. Their work, which goes far beyond the scope of this paper, undergirds and is fundamental to reframing sustainability from economic, ecological, political and social positions.

By defining the economy as 'culturally-instituted habits for material provisioning and accumulation' (Zein-Elabdin 2003), feminist economists open the door to envisioning economies in a more socially and ecologically sustainable way.

The following sections touch on a range of themes in feminist work which, from an ecological economics viewpoint, are applicable and relevant to the issue of sustainability. These feminist themes provide additional insights related to the two types of 'reframe' mentioned above, which we can call the 'materially-delinked growth' and the 'flourishing services' approaches to achieving democratic redistribution along with throughput reduction.

The feminist authors discussed in this paper hold a wide range of political positions; some are radical critics of capitalism and/or neoclassical economics while others work within or try to expand the neoclassical paradigm. Some are ecofeminists while others do not see themselves as ecofeminists at all. The point of this very brief and exploratory review is not to categorize them, but to indicate the range and richness of feminist contributions to debates on sustainability, and to draw out some themes and connections.

\section{Materially-delinked growth}

Delinking economic growth from resource throughput implies applying more labor per unit of material resources, and/or acknowledging the labor essential to economic growth. Feminist work on services, especially caring services, crucially underlies analyses of sustainability and economic growth (Chodorow 1978, 2000). American feminist economist Nancy Folbre has traced the history of social reproduction and its relation to the counted and uncounted economy in her books Who Pays for the Kids? and The Invisible Heart. She writes (Folbre 1994, pp. 254 255), "Economists should challenge the traditional assumption that families "naturally" produce future workers, and that the only way they can go wrong is if they produce too many. The global economy faces a crisis of social reproduction.... The current organization of social reproduction is unfair, inefficient, and probably unsustainable.' Along with many other feminist economists such as Susan Himmelweit, Maren Jochimsen, and Gillian Hewitson, she has explored the implications of unpaid 'caring' work and has proposed policy approaches that help to bring this important work into the foreground.

One ecologically-related question is, if providers of formerly-unpaid work began to receive payment at equitable wage rates, would their overall consumption increase, fueling throughput-intensive growth? Or does their consumption also take place outside the market, in which case there might be no additional ecological 
drain? And even if more consumption were to ensue, is this not justified on equity grounds and/or because consumption by care-givers benefits the cared-for as well? Empirical work is clearly needed to answer these questions, which may have very different answers in the global North and South, depending on factors such as the overall degree of monetization of the economy. This is an important issue since the monetary value of unpaid work has been estimated at roughly 50 percent of measured GNP (Pietila 1997).

Feminist economists and sociologists have grappled with the questions of whether and how to value unpaid work and the difficulty of measuring it in monetary terms, how to account for multi-tasking and multiple functions, and the different social locations of market actors, and how to escape or pose alternatives to the market as the only site for economic transactions; see the section on 'time' below (Henderson 1992; McMahon 1997; Eichler 1999; Hawthorne 2002; Feiner 2003).

Susan Himmelweit's (2003) 'evolutionary approach' to modeling economic behavior such as unpaid work, which explores the relationships between individual and societal processes, and S. Charusheela's (2003) critique of wage bargaining in the context of differential social power relations, provide examples of the theoretical richness of this area of feminist economics and its relevance to the concept of 'materially-delinked growth'.

In a recent paper in the journal Ecological Economics, Minna Halme etal. (2002) discussed the relation between social and ecological or material sustainability in their analysis of sustainable household services. They pointed out that most private consumption occurs in the household context, and after summarizing the literature on a variety of existing sustainability indicators, proposed a way of assessing the sustainability of household quality-of-life improvements. Their 18 indicators include material use, energy use, water use, waste and emissions, space use, transport, organic products, equity, health, safety/security, comfort, social contacts, empowerment, information/awareness, employment, financial situation, regionality, and profitability.

Diane Elson (1998, p. 167) has commented that 'the adequacy of growth models in relation to human development objectives can be linked to the way in which growth models treat the interaction of production and social reproduction.' She (1998, p. 156) advocates 'transforming conceptual tools rather than integrating women into the existing paradigm, and ... the democratic transformation of public debate and policy processes.' These steps are arguably necessary for ecological sustainability as well, if there is to be a democratic transition to less materiallybased economies. Democracy implies fair opportunities and access to the material resources of the socio-economy, which is increasingly important under conditions of growing overall material scarcity.

So the contributions of feminist analysis to the discussion of materially-delinked growth focus on understanding and measuring unpaid work and social reproduction services, equitable division of the material benefits of work since these are also 
inputs to work/service provision, and democratic policies to stimulate better and more sustainable service provision even for non-marketed services.

\section{Flourishing services: quality, quantity, and value}

What about removing barriers so that unpaid and non-marketed activities can flourish? One method involves looking beyond markets and monetization as compensation mechanisms.

In the face of patently unjust gendered economic systems, feminists have long sought ways of measuring value which do not rely on money and markets. In the U.K., Mary Mellor etal. (2004) have explored the question of money and value in their book The Political Economy of Money, and Raff Carmen (1994) has highlighted human agency and coordination as the key element in development. German ecofeminist Veronika Bennholdt-Thomsen (2001) has also pointed out that human well-being depends largely on reciprocal subsistence-based activity, not money.

Local-currency and Local Exchange Trading Systems (LETS) advocates - even those who do not identify as feminists - have argued that dependence on money for economic provisioning is unnecessarily restrictive, and that people who do not have access to money can and do nonetheless make huge contributions to local economies. LETS facilitates exchanges of locally-provided goods and services among community members who can earn and draw down credits in the system based on their transactions, with no need for currency. This means the multiplier and job-creation effects of the transactions stay within the local area, which can provide many social and environmental benefits (Nozick 1992, Roberts \& Brandum 1995; Shuman 1998). Mary-Beth Raddon (2002) has pointed out that community currencies provide one way of acknowledging the value of unpaid work while minimizing throughput growth associated with its valorization, and that the social relationships fostered in community currency groups are also an important component of sustainability.

Other feminists such as Julia Kristeva (1981) and Bronwyn Davies (1990) have discussed the theoretical and political dichotomy between valuing unpaid/women's work in money terms and thus accepting the valuation systems of the maledominated economy, vs. developing more holistic non-monetary measures of value (see Salleh 1994; Raddon 2003). Ecological economists will recognize the parallels with ongoing debates on whether environmental and ecological factors should/can be valued in money terms alone.

The multiplier effects and value-creation which are possible in non-monetized socioeconomic systems are virtually unlimited and not subject to external control. Just as community budgeting practices in Brazil and elsewhere (Santos 1998; Schugurensky 2001) allow the growth and sharing of political power, alternative value-systems allow the growth and sharing of economic power, without imposed limits. 
'Discourse-based valuation' and similar processes for estimating comparative values of non-marketed services and amenities, discussed below, are further ways of bringing alternative and collaborative value systems into economic contexts (Perkins 2001; Wilson \& Howarth 2002). Their educational and political effects in bringing about a common understanding and acceptance of joint strategies for sustainability can facilitate a democratic transition to lower-throughput economies.

\subsection{Beyond markets: intersubjectivities and exchange as intelligent relationships}

Another major contribution of feminist economics has been its powerful critique of the capitalist ideology of individual economic actors pursuing their separate self-interest in market-based exchange (Ferber \& Nelson 1993; Gibson-Graham 1996; Nelson 1997). A range of alternatives to economic allocation mechanisms based on competition and individual preferences have been proposed by feminist and other heterodox economists.

Paul Langley \& Mary Mellor (2002, p. 1) have defined sustainability as 'combining conditions of existence where human beings achieve their potential without exploiting the labor and resources of other individuals, groups or societies with a level of ecological replenishment necessary not only for human futurity but for the continued existence of other species and their ecosystems.' They (2002, pp. 24-25) have discussed systems for provisioning which avoid the many drawbacks of markets, and described 'associational-voluntaristic provisioning practices', in which people come together in self-organized groups such as cooperatives and local exchange trading systems, as a way of avoiding traditional patterns of inequality, introducing democracy, and reclaiming political space by countering globalization.

Like German ecofeminist Maria Mies (1998), Julie Nelson (2003) has described economic exchange as a creative moral process, and urged the reintegration of economics and morality. In her view, there is no apriori reason why economic exchange cannot take social learning and complex feedback relationships as its model, instead of unrealistic, simplistic selfishness.

All of these ideas contribute to a vision of how sustainable exchange practices and productive, just relationships can flourish, thus enhancing the quality of life.

\section{2. $\quad$ Starting from local places}

The importance of context, groundedness, and local specificities is a recurring theme in feminist and ecofeminist work (see, for example, Merchant 1992; Salleh 1997, Mellor 1997b, Mies \& Bennholdt-Thomsen 1999). In particular, feminists have critiqued the idea of an objective and universalizing reality, and have emphasized reflexive self-awareness and empathic identification in both theoretical and activist work. $^{7}$ 
Ecological feminist work which has expanded on the importance of local context in economic transformation and sustainability includes that of Canadians Marcia Nozick (1992); Helen Forsey (1993), and Ellie Perkins (2003), and British author Helena Norberg-Hodge (1994).

Michal Osterweil's (2002, p. 149) recent literature review in Development outlined a number of feminist writings on the politics of place and local strategies for economic transformation - the 'multiple micro-levels in which women - throughout the world - are articulating their demands.'

This body of work emphasizes the fact that sustainability can only be practically defined and understood in specific contexts, for ecological as well as political and relationship-based reasons. Generalizations tend to lead to exploitation, misunderstandings, power inequities, and management errors, while perpetuating harmful and misguided approaches. The sustainability conundrum can only be effectively addressed at small scales. ${ }^{8}$

\subsection{Collective decision-making and global justice}

Feminist research on alternative valuation processes and public participation, including North American work on 'discourse-based valuation', has engaged with questions of how to overcome social power inequities and redress injustices at the global and local levels (Perkins 2001, 2003, 2005). Since democracy and public involvement are usually regarded as fundamental for sustainability, existing social inequities based on gender and ethnicity must be addressed as part of any economic transition. In particular, focus on local transformation in the global economic North is not acceptable if this implies leaving gender and class inequities vis-à-vis the global economic South unaddressed. ${ }^{9}$

Feminist political scientists in Europe and North America are developing pluralist, inclusive conceptions of 'citizenship' which incorporate social difference, bridge public-private and earner-carer divides, recognize the importance of informal political organizing, and incorporate an understanding of time as an essential political resource (see, for example, Ruth Lister 1997; Joan Landes 1998).

\subsection{Institution-building for sustainability}

Like many ecological economists (see Lehtonen 2004), many feminists are concerned with how to create institutions and social structures which can facilitate change for a better future. Some are more impatient than others about the value of working for gradual change within current political frameworks. For example, the 'subsistence perspective' of a number of ecofeminist economists including Maria Mies, Veronika Bennholdt-Thomsen, Claudia von Werlhof, Vandana Shiva, and others, is an approach which calls for local production to meet local needs and 
which rejects many aspects of the globalized economy. Other feminists seek to transform political institutions, calling into question the public-private divide and socially reorganizing both paid and unpaid work so that everyone is able to participate equally as citizens. As Sherilyn Macgregor (2004, p. 77) has stated, 'Citizenship discourse has the potential to politicize women's environmental concerns, to assert that they are not mere "motherhood issues" but deeply political ones that should become relevant to all citizens regardless of their private identities if a sustainable, democratic, and egalitarian society is to be possible.'

Other areas in which feminist work has contributed to understanding how human communities flourish and grow include: interpersonal well-being and community (see Veronika Bennholdt-Thomsen 2001 on localization and cities, and Marcia Nozick 1992 on the economic value of physical and emotional health, good parenting, and emotional security in communities); human/non-human continuum and future generations (see Karen Warren 1997) on the dangers of anthropocentrism, and Barbara Adam (1998) on 'wisdom'); and transmission of skills for living well. Many feminists as well as others have studied the transmission of social skills and social reproduction; there is a vast literature on how this takes place, its gendered nature, changes over time, new demands on those responsible for skills transmission, and policies to improve this process. ${ }^{10}$

This work's connection with sustainability, as noted above, is that policies to assist processes of social reproduction, equitable citizenship, subsistence provisioning, democratic environmental valuation, collective and community-based decisionmaking, local indicators of economic transformation, social learning, and nonmonetary exchange relationships, all contribute to the flourishing of non-materially derived human well-being which has economic value and is integral to growth and development.

\section{Diversity, heterodoxy and feminist ecological approaches to economics in theory and practice}

Besides helping to reframe approaches to the sustainability conundrum as discussed in the previous section, feminist economists have made several other conceptual contributions to ecological economics which are related to sustainability and growth. They are discussed in the following sections on modeling, time, and activism-based theory.

\subsection{Modeling}

In the modeling approach of Finnish economist Hilkka Pietilä (1997), the economy is represented as a series of concentric circles (Figure 1). Household and community production and reproduction are at the centre of economic focus, because 


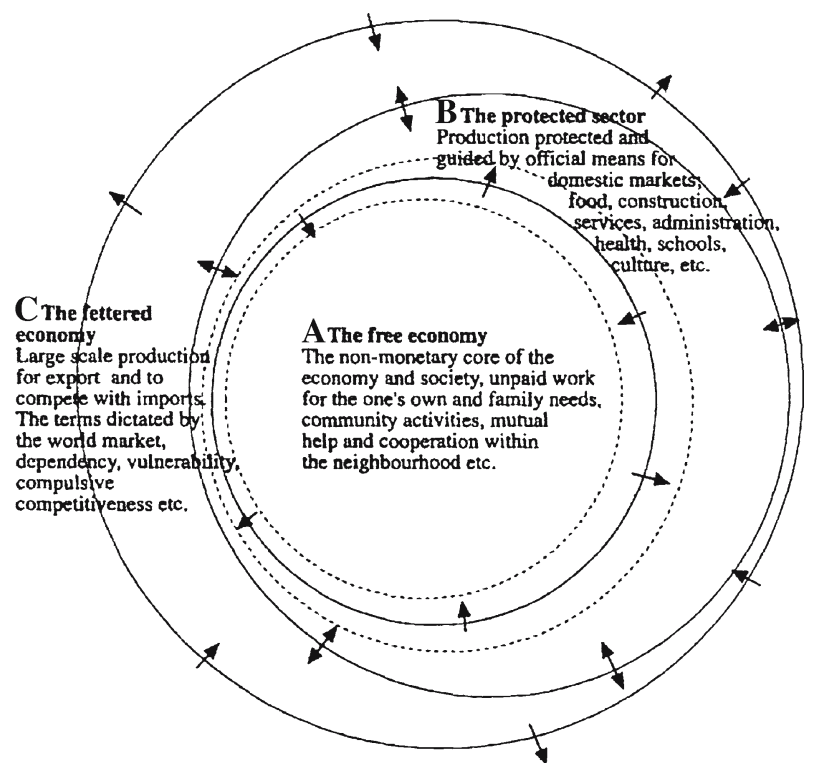

Figure 1. Pietilä's model of national economies.

without human beings and the society in which they live, the economy has no meaning. The model thus takes as a starting point the unpaid work which is vitally necessary to build and maintain homes, human relationships, and communities and without which there can be no 'economy'.

Since most of this core economic activity takes place with no monetary exchange, Pietilä calls this the 'free' economy. The free economy is surrounded by economic activities which are controlled by governments, either directly or due to central-bank money supply controls and other market regulations; this is the 'protected' domestic market sector. Surrounding the protected economy is the 'fettered' economy, susceptible to the terms of trade and vagaries of the world market. The farther you go from the centre, the more unstable, disconnected, and uprooted people become - both socially and ecologically.

Pietilä has discussed the implications of this model in terms of the need to preserve skills, resources, and know-how for household production, allow time for household activities and reduce time spent in outside work, organize communities spatially to reflect the centrality of home life, and adopt the new, critical perspective on economic growth which flows from the model.

Swiss economists Maren Jochimsen \& Ulrike Knobloch (1997) have also developed a three-part model of economic activity (Figure 2). This relates the 'maintenance economy', of ecological processes, and the social and physical relations which are indispensable for human existence (and which are often carried out without payment of money), to the industrial economy. 


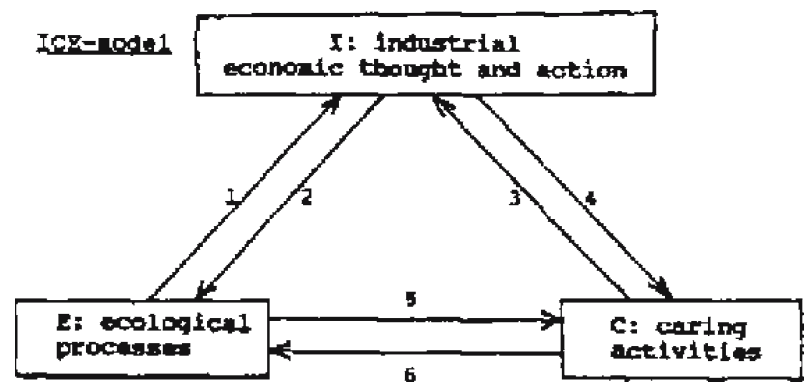

Figure 2. Jochimsen \& Knobloch's model of industrial economic thought and action, caring activities, and ecological processes.

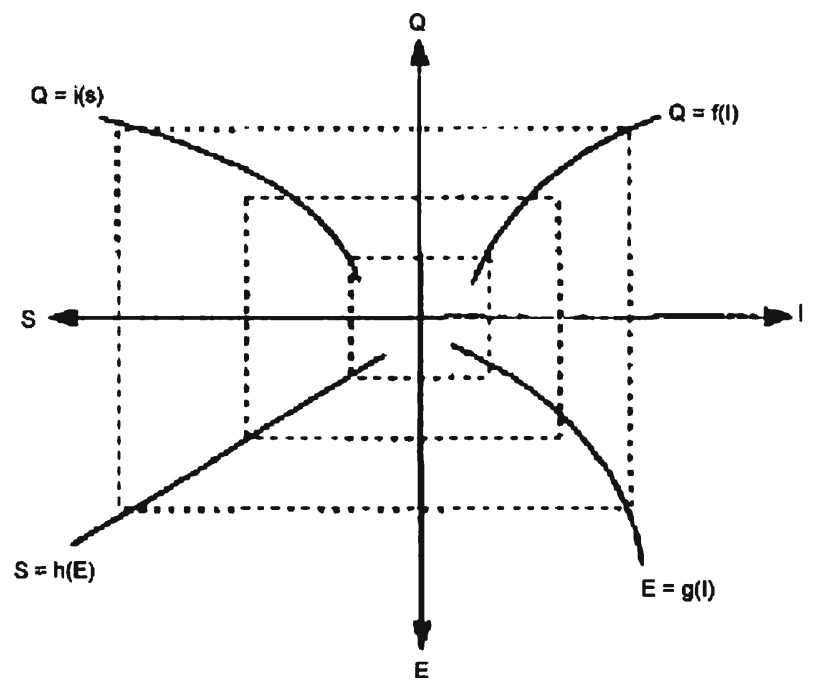

Figure 3. O'Hara's model of production processes.

These same interrelationships and trade-offs among industrial production, inputs from nature, pollution, and sustaining (household and social) services are shown in American economist Sabine O'Hara's (1997) modelling framework (Figure 3). In this graph, Q is the level of output, I stands for the traditional inputs into the productive process (labor, capital, and materials), E stands for emissions, and $\mathrm{S}$ stands for sustaining services which are required for production to take place both environmental and social. Output Q is a function of inputs I, but also of sustaining services $\mathbf{S}$. Emissions grow as input-use increases, but this causes damage to sustaining services, which eventually has a limiting effect on output.

In effect, by depicting production quantity as a trade-off between materials throughput and damage to sustaining services via emission rates, this model allows the balances between inputs, outputs, emissions and sustaining services to be 
shown all at once. Herman Daly and others have been engaged with this problem for at least ten years, and O'Hara's (1997) model makes a significant contribution. She says that estimating the functional forms of these interrelationships clearly requires a lot more detailed and context-specific empirical work. Essential in this process is what she calls 'moving from abstraction to concreteness'. For example, the conditions under which production can take place require physical (not solely monetary) measures of material flows, and a diversity of methodological and conceptual approaches. The latter implies democratic, open decision-making, interpersonal justice, communication, and 'discourse', to use O'Hara's term.

\subsection{Conceptualizations of time in relation to the economy}

Another theme in feminist ecological economics is attention to the question of time. This includes a range of theoretical issues as well as practical ones, like multitasking and respect for the time and effort it takes to be green. Who will do the work of growing the tomatoes on urban rooftops, recycling the post-consumer materials, carrying the glass jars to the bulk food stores to be refilled with beans, soaking and cooking and refrying the beans? Both production and re-production take time; technology cannot do away with the time natural reproduction takes, as Australian philosopher Teresa Brennan (1997) pointed out, which is an important link between human societies/economies and the natural world. Even when technology speeds up production, this happens at a cost, and technology cannot substitute for the basic and essential value which comes from nature.

Reconceptualizing time and temporal complexity is necessary in order to be able to even conceive of a sustainable socio-economy. As British sociologist Barbara Adam (1998, p. 9) has written, 'Industrial time is centrally implicated in the construction of environmental degradation and hazards.... As long as time is taken for granted as the mere framework within which action takes place and is used in a pre-conscious, pre-theoretical way... it will continue to form a central part of the deep structure of environmental damage wrought by the industrial way of life.'

Mary Mellor $(1992,1997 \mathrm{a}, \mathrm{b})$ also writes about the idea of time, pointing out the distinction between social (or 'clock') time and natural or biological time, emphasizing the different roles of women and men in relation to each, and the importance of learning to live in 'biological time' - as most women do, at least while undertaking traditional domestic labor.

\subsection{Collective, activism-based theory}

Another way in which feminists continue to make a large contribution to sustainability is in demonstrating how community activism and engagement in the process of social change is a source of useful information for theorizing. Partly due to 
its emphasis on the importance of communal processes, diverse ways of knowing, non-monetary or discourse-based valuation, and methodological pluralism, feminist ecological economics implies working with other people to learn about and change the current unsatisfactory state of things. As Vandana Shiva (1989) has pointed out, there are many feedbacks between local activist work and theoretical insights regarding how economic and ecological processes work at the global level.

Hilkka Pietilä (1997) has used her model to attempt to estimate the size of the three concentric circles in Finland and other Scandinavian countries. Such estimations, done periodically over time, give an indication of economic changes which can endanger the sustaining services of the society. To give an example, international trade agreements which subsidize centralized production restrict the ability of growing local economies to provide goods and services locally. The information used in these estimations would, in addition, be useful inputs for estimating the functions on Sabine O'Hara's graph, which as noted provides information on the optimal size of a functional economy.

The triangle model of Maren Jochimsen \& Ulrike Knobloch (1997) provides a useful framework for investigating the links between industrial production, toxic contaminants, and reproductive disruption in humans and animals. The feedbacks, both in terms of healthcare costs and lost future economic potential in agriculture and industry, can be traced around the triangle model framework.

Many theorists of feminist ecological economics are engaged in tracking the effects of globalization in their own communities, and in helping to build locallyviable economic alternatives. Their writing exemplifies the groundedness and accuracy that comes from this first-hand knowledge of conditions and people in their own local places.

\section{Conclusion}

There are good reasons why feminist and ecological approaches to economic transformation are intertwined and interdependent (Friedrich Engels 1942, Maria Mies 1986, Mary Mellor 1992, 1997a), so understanding and drawing from feminist perspectives can strengthen ecological economics both theoretically and in its uses and applications.

In fact, feminist analyses are helping to generate new visions of social and ecological sustainability - and to show how to bring it into existence. These contributions include creative modelling approaches as well as intensive theoretical work on such economically-important issues as social reproduction, alternative and non-market valuation processes, local and community-based economies, quality of life, time, equity, citizenship, and democratic institution-building. They also involve commitments to groundedness, relationship and identity awareness, and involvement in social change as a basis for theory. 
Feminists' interests in and expertise on unpaid work and caring services link directly to analysis of the value of ecological services, and how economic growth and development need not rely primarily on material throughput. Policies which remove barriers to the flourishing of formerly unacknowledged and uncompensated activities and processes will help to make economies more sustainable. Feminist contributions emphasize that democracy and equity, far from being incompatible with the transition to sustainability, are fundamental.

\section{Acknowledgements}

The author would like to thank participants at the CANSEE conference in October, 2005 and several anonymous reviewers for their helpful comments.

\section{Notes}

1. On the fundamental importance of unpaid / women's work in sustaining economies, and the reasons why this is generally unacknowledged, see Friedrich Engels (1942); Maria Mies (1986/1998); Mary Mellor (1992), Marilyn Ferber \& Julie Nelson (1993), J.K. Gibson-Graham (1996), Drucilla Barker \& Edith Kuiper (2003), and Elizabeth Mayes (2005), among others. On the connections between gender and environment in economic theorizing, see Mary Mellor (1997a), Maria Mies \& Veronika Bennholdt-Thomsen (1999), Dianne Rocheleau et al. (1996), articles in a special issue of Ecological Economics on women, ecology and economics (February 1997), and articles in a special section of Feminist Economics on ecological issues (November 2005).

2. Of course, growth itself is also fraught with conflict.

3. See for example Tim Jackson (1996), Juan Martinez-Alier (1999), Brian Milani (2000).

4. See Hazel Henderson (1978, 1980, 1983); Marilyn Waring (1989); Brian Milani (2000); Helena Norberg-Hodge (2001).

5. Herman Daly (1996, p. 31) calls the first 'growth' and the second 'development'; I believe we can draw finer distinctions and recognize that economic growth is in fact possible without material throughput.

6. Work on alternative economic indicators like the Index of Sustainable Economic Welfare, Genuine Progress Indicator, Redefining Progress, parallel GNP accounts measuring ecological services, and local indexes of sustainability such as the one developed by Halifax-based GPI Atlantic, are examples of the expansion of this branch of ecological economics.

7. See Harding \& Hintikka (1983); Harding (1991), and Nelson (1992), among many others.

8. Non-feminist writers have also come to this conclusion; see Thomas Prugh et al. (2000).

9. This is consistent with the 'human security' approach recently adopted by the United Nations (see http://ochaonline.un.org/webpage.asp?Page=1516 and http://www.unhistory.org/publications/humansec html and http://www.gdrc.org/sustdev/husec/Definitions.pdf).

10. See, for example, Nancy Chodorow (1978), Antonella Picchio (1992); Nancy Folbre (1994, 2001, 2003); Susan Himmelweit (2001); Cindi Katz (2001), Susan Feiner (2003).

\section{References cited}

Adam, Barbara. 1998. Timescapes of modernity: the environment and invisible hazards. Routledge, New York. 
Barker, Drucilla K. \& Edith Kuiper. (ed.) 2003. Toward a feminist philosophy of economics. Routledge, New York.

Bennholdt-Thomsen, Veronika. 2001. What really keeps our cities alive, money or subsistence? Pp. 217231 in V. Bennholdt-Thomsen, N. Faraclas \& C. Von Werlhof (ed.) There Is An Alternative: Subsistence and Worldwide Resistance to Corporate Globalization. Zed Books, New York.

Braidotti, Rosi. 1999. Towards sustainable subjectivity: a view from feminist philosophy. Pp. 74-95 in E. Becker \& T. Jahn (ed.) Sustainability and the Social Sciences. Zed Books, New York.

Brennan, Teresa. 1997. Economy for the earth: the labour theory of value without the subject/object distinction. Ecological Economics 20(2):175-185.

Carmen, Raff. 1994. The logic of economics vs. The dynamics of culture: daring to (re)invent the common future. Pp. 60-74 in W. Harcourt (ed.) Feminist Perspectives on Sustainable Development. Zed Books: New Jersey.

Charusheela, S. 2003. Empowering work? Bargaining models reconsidered. Pp. 287-303 in D.K. Barker \& E. Kuiper (ed.) Toward a Feminist Philosophy of Economics. Routledge, New York.

Chodorow, Nancy. 1978. The reproduction of mothering. University of California Press, Berkeley, CA.

Chodorow, Nancy. 2000. Reflections on the reproduction of mothering - twenty years later. Studies in Gender and Sexuality 1(4):337-348.

Code, Lorraine. 2006. Ecological thinking: the politics of epistemic location. Oxford University Press, New York.

Cuomo, Chris. 1997. Feminism and ecological communities: an ethic of flourishing. Routledge, New York.

Daly, Herman. 1996. Beyond growth: the economics of sustainable development. Beacon Press, Boston.

Davies, Bronwyn. 1990. The concept of agency: a feminist post-structuralist analysis. Social Analysis: Journal of Culture and Social Practice 29:42-53.

Eichler, Margrit. 1999. Sustainability from a feminist sociological perspective: a framework for disciplinary reorientation. Pp. 182-206 in E. Becker \& T. Jahn (ed.) Sustainability and the Social Sciences. Zed Books, New York.

Elson, Diane. 1998. Talking to the boys: gender and economic growth models. Pp. 155-170 in C. Jackson \& R. Pearson (ed.) Feminist Visions of Development: Gender Analysis and Policy. Routledge, New York.

Engels, Friedrich. 1942. The origin of the family, private property, and the state. International Publishers, New York.

Feiner, Susan. 2003. Reading neoclassical economics: toward an erotic economy of sharing. Pp. 180-193 in D.K. Barker \& E. Kuiper (ed.) Toward a Feminist Philosophy of Economics. Routledge, New York.

Ferber, Marianne \& Julie Nelson. (ed.) 1993. Beyond economic man: feminist theory and economics. University of Chicago Press, Chicago.

Folbre, Nancy. 1994. Who pays for the kids? Gender and the structures of constraint. Routledge, New York.

Folbre, Nancy. 2001. The invisible heart: economics and family values. New Press, New York.

Folbre, Nancy. 2003. Holding hands at midnight: the paradox of caring labour. Pp. 213-230 in D.K. Barker \& E. Kuiper (ed.) Toward a Feminist Philosophy of Economics. Routledge, New York.

Forsey, Helen. (ed.) 1993. Circles of strength: community alternatives to alienation. New Society Publishers, Philadelphia/Gabriola Island.

Gibson-Graham, J.K. 1996. The end of capitalism (as we knew it): a feminist critique of political economy. Blackwell, Malden, MA.

Halme, Minna, Christine Jasch \& Michael Scharp. 2002. Sustainable homeservices? Toward household services that enhance ecological, social and economic sustainability. Ecological Economics 51(1-2):125-138.

Harding, Sandra \& Merrill B. Hintikka. (ed.) 1983. Discovering reality: feminist perspectives on epistemology, metaphysics, methodology, and philosophy of science. D. Reidel, Dordrecht/Boston. [Republished in 2003] 
Harding, Sandra. 1991. Whose science? Whose knowledge? Thinking from women's lives. Cornell University Press, Ithaca.

Hawthorne, Susan. 2002. Wild politics. Spinifex Press, Australia.

Henderson, Hazel. 1978. Creating alternative futures. Perigee Books, New York.

Henderson, Hazel. 1980. The politics of the solar age. Knowledge Systems, New York.

Henderson, Hazel. 1983. The warp and the weft: the coming synthesis of eco-philosophy and eco-feminism. Pp. 203-214 in L. Caldecott \& S. Leland (ed.) Reclaim the Earth. The Women's Press, London.

Henderson, Hazel. 1992. Paradigms in progress: life beyond economics. Knowledge Systems, Indianapolis.

Hewitson, Gillian J. 2003. Domestic labour and gender identity: are all women carers? Pp. 266-284 in D.K. Barker \& E. Kuiper (ed.) Toward a Feminist Philosophy of Economics. Routledge, New York.

Himmelweit, Susan. 2001. Caring for children. Pp. 179-199 in S. Himmerlweit, R. Simonetti \& A. Trigg (ed.) Microeconomics: Neoclassical and Institutionalist Perspectives on Economic Behaviour. Thomson Learning, London.

Himmelweit, Susan. 2003. An evolutionary approach to feminist economics: two different models of caring. Pp. 247-265 in D.K. Barker \& E. Kuiper (ed.) Toward a Feminist Philosophy of Economics. Routledge, New York.

Jackson, Tim 1996. Material concerns: production, profit and quality of life. Routledge, New York.

Jochimsen, Maren A. 2003. Integrating vulnerability: on the impact of caring on economic theorizing. Pp. 231-246 in D.K. Barker \& E. Kuiper (ed.) Toward a Feminist Philosophy of Economics. Routledge, New York.

Jochimsen, Maren \& Ulrike Knobloch. 1997. Making the hidden visible: the importance of caring activities and their principles for any economy. Ecological Economics 20(2):107-112.

Katz, Cindi. 2001. Vagabond capitalism and the necessity of social reproduction. Antipode 33(4):709.

Kristeva, Julia. 1981. Women's time. Signs 7(1):13-35.

Landes, Joan B. (ed.) 1998. Feminism, the public and the private. Oxford University Press, Oxford/ New York.

Langley, Paul \& Mary Mellor. 2002. 'Economy', sustainability and sites of transformative space. New Political Economy 7(1):49-65.

Lehtonen, Markku. 2004. The environmental - social interface of sustainable development: capabilities, social capital, institutions. Ecological Economics 49(2):199-214.

Lister, Ruth. 1997. Citizenship: feminist perspectives. New York University Press, New York.

Macgregor, Sherilyn. 2004. From care to citizenship: calling ecofeminism back to politics. Ethics and the Environment 9(1):56-84.

Martinez-Alier, Juan. 1999. The socio-ecological embeddedness of economic activity: the emergence of a transdisciplinary field. Pp. 112-139 in E. Becker \& T. Jahn (ed.) Sustainability and the Social Sciences. Zed Books, London/New York.

Mayes, Elizabeth. 2005. Private property, the private subject, and women: can women truly be owners of capital? Pp. 117-130 in M.A. Fineman \& T. Dougherty (ed.) Feminism Confronts Homo Economicus: Gender, Law and Society. Cornell University Press, Ithaca/London.

McMahon, Martha. 1997. From the ground up: ecofeminism and ecological economics. Ecological Economics 20(2):163-174.

Mellor, Mary. 1992. Breaking the boundaries: toward a feminist green socialism. Virago, London.

Mellor, Mary. 1997a. Feminism and ecology. New York University Press, New York.

Mellor, Mary. 1997b. Women, nature, and the social construction of 'Economic Man.' Ecological Economics (20)2:129-140.

Mellor, Mary, Frances Hutchinson \& Wendy Olsen. 2004. The political economy of money.

Merchant, Carolyn. 1992. Radical ecology. Routledge, New York.

Mies, Maria. 1986/1998. Patriarchy and accumulation on a world scale. Zed Books, New York.

Mies, Maria \& Vandana Shiva. 1993. Ecofeminism. Zed Press, London. 
Mies, Maria \& Veronika Bennholdt-Thomsen. 1999. The subsistence perspective: beyond the globalized economy. Zed Books, New York.

Milani, Brian. 2000. Designing the green economy: the post-industrial alternative to corporate globalization. Rowman and Littlefield, Lanham, MD.

Nelson, Julie. 1997. Feminism, ecology and the philosophy of economics. Ecological Economics 20(2): $155-162$.

Nelson, Julie. 2003. How did 'the moral' get split from 'the economic'? Pp. 134-142 in D.K. Barker \& E. Kuiper (ed.) Toward a Feminist Philosophy of Economics. Routledge, New York.

Norberg-Hodge, Helena. 1994. Building the case against globalization and for community-based economies. International Society for Ecological Economics Newsletter 5(2):3-4.

Norberg-Hodge, Helena. 2001. Local lifeline: rejecting globalization - embracing localization. Pp. 178188 in V. Bennholdt-Thomsen, N. Faraclas \& C. Von Werlhof (ed.) There Is An Alternative: Subsistence and Worldwide Resistance to Corporate Globalization. Zed Books, New York.

Nozick, Marcia. 1992. No place like home. Ottawa: Canadian Council on Social Development.

O'Hara, Sabine. 1997. Toward a sustaining production theory. Ecological Economics 20(2):141-154.

Osterweil, Michal. 2002. Women negotiating place: a review of current feminist writings. Development 45 (1):148-151.

Perkins, Ellie. 2001. Discourse-based valuation and ecological economics. Paper presented at the CANSEE conference, McGill University, 23-25 August.

Perkins, Ellie. 2003. Social diversity, globalization and sustainability in community-based economies. Canadian Woman Studies 23(1):38-46.

Perkins, Ellie. 2005. Public participation and ecological valuation: inclusive $=$ radical. Paper presented at the Capitalism Nature Socialism conference, York University, July 22-24.

Picchio, Antonella. 1992. Social reproduction: the political economy of the labour market. Cambridge University Press, Cambridge/New York.

Pietilä, Hilkka. 1997. The triangle of the human economy: household - cultivation - industrial production. An attempt at making visible the human economy in toto. Ecological Economics 20(2):113-128.

Plumwood, Val. 1993. Feminism and the mastery of nature. Routledge, New York.

Plumwood, Val. 2002. Environmental culture: the ecological crisis of reason. Routledge, New York.

Prugh, Thomas, Robert Costanza \& Herman Daly. 2000. The local politics of global sustainability. Island Press, Washington, DC.

Raddon, Mary-Beth. 2002. Community and money: caring, gift-giving, and women in a social economy. Black Rose Books, Montreal.

Raddon, Mary-Beth. 2003. Community currencies: value and feminist politics. Women and Environments International 54/55.

Roberts, Wayne \& Susan Brandum. 1995. Get a life: how to make a good buck, dance around the dinosaurs, and save the world while you're at it. Get a Life Publishing House, Toronto.

Rocheleau, Dianne, Barbara Thomas-Slater \& Esther Wangari. 1996. Feminist Political Ecology: Global Issues and Local Experiences. Routledge, New York.

Salleh, Ariel. 1994. Nature, woman, labour, capital: living the deepest contradiction. Pp. 106-124 in M. O'Connor (ed.) Is Capitalism Sustainable? Guilford, New York.

Salleh, Ariel. 1997. Ecofeminism as politics: nature, Marx and the postmodern. Zed Books, New York.

Santos, Boaventura De Sousa. 1998. Participatory budgeting in Porto Alegre: toward a redistributive democracy. Politics and Society 26(4):461-498.

Schugurensky, Daniel. 2001. Grassroots democracy: the participatory budget of Porto Alegre. Canadian Dimension 35(1):30.

Shiva, Vandana. 1989. Staying alive. Zed Press, London.

Shuman, Michael. 1998. Going local: creating self-reliant communities in a global age. The Free Press, New York. 
Waring, Marilyn. 1989. If women counted. Macmillan, London.

Warren, Karen. 1997. Ecofeminism: women, culture, nature. Indiana University Press, Bloomington, IN.

Wilson, Matthew A. \& Richard B. Howarth. 2002. Discourse-based valuation of ecosystem services: establishing fair outcomes through group deliberation. Ecological Economics 41(3):431-443.

Zein-Elabdin, Eiman. 2003. The difficulty of a feminist economics. Pp. 321-338 in D.K. Barker \&

E. Kuiper (ed.) Toward a Feminist Philosophy of Economics. Routledge, New York. 